\title{
CONTEMPORARY MARKETING PRACTICES APPROACHES IN THE PROFESSIONAL SERVICES INDUSTRY IN BRAZIL
}

\section{PRÁTICAS CONTEMPORÂNEAS DE MARKETING NA INDÚSTRIA DE SERVIÇOS PROFISSIONAIS NO} BRASIL

\section{Lenoir Hoeckesfeld}

Recebido em 05.12.2019 Aprovado em 11.03.2020

Avaliado pelo sistema double blind review

leno.adm@gmail.com

Doutorando em Administração (UNIVALI) e professor do Instituto Federal de Mato Grosso (IFMT) Campus Alta

Floresta, MT - Brasil.

ORCID: https://orcid.org/0000-0002-1339-1157

\begin{abstract}
Aléssio Bessa Sarquis
alessio.sarquis@gmail.com

Doutor em Administração pela Universidade de São Paulo (USP) e professor do Programa de Pós-Graduação

Mestrado em Administração (PPGA) da Universidade do Sul de Santa Catarina (UNISUL), SC - Brasil.

ORCID: http://orcid.org/0000-0001-9690-0510
\end{abstract}

\section{André Torres Urdan}

andre.urdan@gmail.com

Doutor em Administração pela Universidade de São Paulo (USP) e professor da Universidade Nove de Julho (UNINOVE), SP - Brasil.

ORCID: https://orcid.org/0000-0002-4816-0973

\section{Eric David Cohen}

ericdcohen@gmail.com

Doutor em Administração de Empresas pela Fundação Getúlio Vargas (FGV) e professor da Universidade Estadual de Campinas, SP - Brasil.

ORCID: https://orcid.org/0000-0003-0994-1731

\begin{abstract}
The objective of this study is to investigate the Contemporary Marketing Practices (CMP) of professional services firms from the State of Santa Catarina in Brazil, according to the models proposed by Coviello, Brodie \& Munro (1997) and Coviello, Milley \& Marcolin (2001). The research methodology has a quantitative and descriptive approach and uses a survey; the sample encompasses 146 companies from the accounting, engineering, consulting, advertising, information technology and hospital industries. Our findings also reveal the existence of seven main business segment typologies: "Advanced Relational"; "Interactive Relational/Network"; "Relational Database/Digital"; "Moderately Relational"; "Conservative I"; "Conservative II" and "Refractory".
\end{abstract}

Keywords: Marketing services. Contemporary marketing practices. Relationship marketing. Professional services.

\section{Resumo}

O objetivo deste estudo é investigar as Práticas Contemporâneas de Marketing (CMP) de empresas de serviços profissionais do Estado de Santa Catarina, Brasil, de acordo com modelos propostos por Coviello, Brodie \& Munro (1997) e Coviello, Milley \& Marcolin (2001). A metodologia da pesquisa possui abordagem quantitativa e descritiva e utiliza a técnica de survey; a amostra abrange 146 empresas dos setores de contabilidade, engenharia, consultoria, publicidade, tecnologia da informação e hospital. Nossas descobertas também revelam a existência de sete principais segmentos de negócios: "Relacional avançado"; "Relacional/Rede Interativo"; "Banco de dados relacional/digital"; "Relacional moderado"; "Conservador I"; "Conservador II" e "Refratário".

Palavras-chave: Marketing de serviços. Práticas contemporâneas de marketing. Marketing de relacionamento. Serviços profissionais. 


\section{Introduction}

The Contemporary Marketing Practices (CMP) concept encompasses multiple marketing methods and tactics that go beyond the traditional marketing mix approach. These include database marketing, digital marketing, interaction marketing, and network marketing (O' Dwyer, Gilmore \& Carson, 2009, Sacramento \& Teixeira, 2014). The level of CMP maturity depends on the manner that the company and clients - or other stakeholders - interact. In one extreme of this continuum, the firm and the consumers interact in a dispassionate way; contacts are detached and impersonal (henceforth, this low degree of contact is dubbed economic transaction orientation). At the other extreme, the interaction is characterized by close contacts that combine customer proximity, long-term continuity and an individualized business relationship (hereafter defined: relationship orientation) (Coviello, Brodie \& Munro, 1997).

The extant marketing literature shows an important international stream of research that has long addressed the organizational Contemporary Marketing Practices. The body of research that stands out from the CMP literature hinges on the practitioner's concern towards the construction of long-term bonds, which seek to leverage customer satisfaction (Rocha \& Luce, 2006). The literature acknowledges, however, the need to maintain some transactional marketing tactics (which still hold).

In this paper, we examine in detail the Professional Services industry. Firms from this industry typically provide expert technical and specialized services for clients who lack the expertise - such as engineering, medical and accounting services (Gummesson, 1978; Gianesi \& Correa, 2000; Amonini, McCollKennedy, Soutar \& Sweeney, 2010; Sweeney, Soutar \& McColl-Kennedy, 2011).

The production and delivery processes in this industry hinge on the skills, training and knowledge of its staff; the inputs, materials and equipment are usually ancillary, and serve to support the service delivery (Gianesi \& Correa, 2000). In that sense, professional services are managed by highly qualified, independent and problem-solving people (Costa, 2013; Patterson, 2016). In this context, the delivery of services entails that the customer relationship must be closely monitored, since the clients become active participants in the production and delivery process (Siluk \& Nora, 2011).

This industry is highly relevant for the global economy and socially important: its gross annual revenues reach US\$ 2.5 trillion, with more than 17 million people employed, with steady growth in recent years (Ibis World, 2016). In Brazil, the service industry (which includes the professional services) accounts for approximately $65 \%$ of the GDP, $41 \%$ of the employed workforce of 5.1 million people; $36.7 \%$ of the wages ( $\mathrm{R} \$ 93.1$ billion) and generates $\mathrm{R} \$ 254.3$ billion in economic value-added (IBGE, 2016).

CMP research in the professional services industry is still incipient (Reid, 2008; Patterson, 2016). Sweeney et al. (2011) posit that marketing standpoints such as performance evaluation and customer relationship practices are still lacking. In this regard, Hoeckesfeld, Sarquis \& Favretto (2017) suggest that it is important to compare firms of different sizes from the same industry.

Most service organizations face increasing competition, and need new sources of competitive advantage (Zeithaml, Bitner \& Gremler, 2014). This is also true in Brazil, which has suffered an economic downturn that has affected the professional services firms' financial performance.

There is a relevant Brazilian scientific production on Relationship Marketing, but needs further development in the professional services industry (De Macedo Bergamo, Giuliani \& Galli, 2011; Faria, Giuliani, Pizzinatto \& Spers, 2014; Soares \& Monteiro, 2015). In line with the CMP framework, Targino, Urdan \& Chauvel (2013) categorized five types of companies (Refractory, Transactional / Interactive, Advanced, Moderate, Unique). These authors proposed to broaden the knowledge of marketing practices, which are driven by the technology advances and the use of internet tools. 
The gap of knowledge in the field prompts us to formally state our research question, namely, to determine the CMP profiles of professional service companies and compare them with the extant research. In addition, we propose to investigate the marketing investment practices, and categorize companies into groups according to their CMP practices, and map the marketing performance metrics.

This article is structured in five sections. In the first part, we present an introductory discussion of the theme and lay out our research objectives. This is followed by the literature review, which presents and articulates the CMP concepts, and discusses the professional services industry. The third section discusses the methodology and the analytical methods employed in the research, followed by a discussion of the results found in light of the extant theory. The last section presents our final considerations, outlines the research contributions and probes for further research possibilities.

\section{Literature Review}

\section{Contemporary Marketing Practices}

The extant research has been concerned with different types of Contemporary Marketing Practices that go beyond the traditional marketing mix (product, price, place and promotion). In fact, CMP encompasses various aspects of customer relationship management that are designed to reach out and fulfill customer expectations. CMP also entails initiatives that use network marketing (which deals with the creation of networks of customers, suppliers and other stakeholders) and digital marketing (defined as the use of electronic tools for communicating and relating with the customer) (Coviello, Brodie, Danaher \& Johnston, 2002; Brodie, Coviello \& Winklhofer, 2008; Reid, 2008, Amonini et al., 2010; Ekman, Erixon \& Thilenius, 2015; Menelec \& Jones, 2015; Farha, Koku, Al-Kwifi \& Ahmed, 2019).

The strand of CMP research began in 1996 from the groundbreaking work by Brodie \& Coviello (the latter, from the University of Auckland, in New Zealand). Specifically, CMP research initiated from a general concern that the focus and approach of Marketing was detached from the changes that occurred in the micro and macro environment (Lindgreen, Di Benedetto, Brodie \& Naudé, 2019). Accordingly, the authors endeavored to map the relationships that involve companies and markets, by looking at transactional marketing tactics. They also contrasted these practices with emerging marketing strategies which promote a relational perspective. Their work identified the relevance of various CMP approaches (Brodie et al., 2008).

In the broad spectrum of CMP practices (Ekman et al., 2015), transaction marketing represents an initial point. The CMP framework considers that it is predicated on the tenets of the Marketing Management school of thought; more specifically, it uses the marketing mix concept, which has long been the dominant paradigm among practitioners (Ekman et al., 2015). According to this orientation, the firm attracts prospects and satisfies customer needs by managing the traditional marketing mix elements. The firm carries out economic transactions, which are often disconnected and occur under formal or impersonal contacts. In this context, the firm actively manages the transactions and communications directed to buyers in a mass market; the practitioner manages the product and the brand to the specific customer segments. Marketing activities are carried out by various functional areas that are supported by internal capabilities, which are linked to the marketing mix elements (Coviello \& Brodie, 2001).

Conversely, in the relational perspective, CMP postulates that long-term relationships with clients and other stakeholders are the most important means of achieving the organization's long-term objectives (Little, Brookes \& Palmer, 2008; Centeno \& Hart, 2012). In this context, the maturity of the CMP processes hinges on the degree of interaction between the firm and its customers and stakeholders (Coviello \& Brodie, 2001; Coviello, Milley \& Marcolin, 2001; Coviello et al., 2002).

The choice of the CMP approach (transactional, or relational) depends on several factors, namely, the target segment expectations, the availability of skills, and the internal resources. Still, practitioners 
increasingly attempt to emphasize relationships with employees, suppliers, customers and other stakeholders (Lindgreen et al. 2019). Along the same line, organizations are increasingly looking for more personalized, closer, and more cost-effective relationships with the relevant stakeholders (Coviello et al., 2001; Ekman et al., 2015). Furthermore, many organizations currently adopt multiple CMP approaches, oftentimes using interchangeable combinations of relationship marketing and classical transaction-based approaches (Centeno \& Hart, 2012). In fact, the transactional and relational approaches are relevant in the contemporary marketing practices (Farha et al. 2019).

Table 1 - Marketing Approaches in the Relational Perspective of the CMP Model.

\begin{tabular}{|c|c|c|c|c|c|}
\hline & Traits & Database Marketing & Digital Marketing & Interactive Marketing & Network Marketing \\
\hline \multirow{5}{*}{ 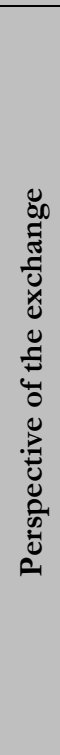 } & $\begin{array}{l}\text { Objective of the } \\
\text { Exchange }\end{array}$ & $\begin{array}{l}\text { Economic information } \\
\text { and transaction }\end{array}$ & $\begin{array}{l}\text { Generating } \\
\text { information dialogue } \\
\text { between seller and } \\
\text { many identified } \\
\text { consumers }\end{array}$ & $\begin{array}{l}\text { Interpersonal } \\
\text { relationships between } \\
\text { buyer and seller }\end{array}$ & $\begin{array}{l}\text { Getting relationships } \\
\text { with other companies } \\
\text { / organizations }\end{array}$ \\
\hline & $\begin{array}{l}\text { Nature of the } \\
\text { communication }\end{array}$ & $\begin{array}{lcc}\text { From company } & \text { to } \\
\text { market segments } & \text { or } \\
\text { target individuals } & \end{array}$ & $\begin{array}{l}\text { Use of technologies } \\
\text { to communicate with } \\
\text { or between groups } \\
\text { and individuals }\end{array}$ & $\begin{array}{l}\text { Individuals with } \\
\text { individuals in the } \\
\text { different units / areas of } \\
\text { the organization }\end{array}$ & $\begin{array}{l}\text { Company to business } \\
\text { (involving individuals) }\end{array}$ \\
\hline & Type of contact & $\begin{array}{ll}\text { Customized } & \text { (but } \\
\text { distance) } & \end{array}$ & $\begin{array}{l}\text { Interactive } \quad \text { (by } \\
\text { technology) }\end{array}$ & $\begin{array}{l}\text { Face-to-face, } \\
\text { interpersonal and close, } \\
\text { based on commitment, } \\
\text { trust and cooperation }\end{array}$ & $\begin{array}{l}\text { Impersonal and } \\
\text { interpersonal } \\
\text { (personal or distance) }\end{array}$ \\
\hline & Duration & $\begin{array}{l}\text { Occasional and over } \\
\text { time }\end{array}$ & $\begin{array}{l}\text { Continuous and with } \\
\text { online interactivity }\end{array}$ & $\begin{array}{l}\text { Continuous and } \\
\text { mutually adapted, short } \\
\text { or long term }\end{array}$ & $\begin{array}{l}\text { Continuous, stable } \\
\text { and dynamic, and may } \\
\text { be short or long term }\end{array}$ \\
\hline & Formality & $\begin{array}{l}\text { Formal (personalized by } \\
\text { technology) }\end{array}$ & $\begin{array}{l}\text { Formal (customized } \\
\text { and / or customized } \\
\text { by interactive } \\
\text { technology) }\end{array}$ & Formal and informal & Formal and informal \\
\hline \multirow{4}{*}{ 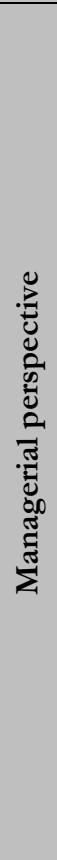 } & $\begin{array}{l}\text { Managerial } \\
\text { objective }\end{array}$ & $\begin{array}{l}\text { Customer retention, } \\
\text { customer satisfaction, } \\
\text { increased profitability } \\
\text { and loyalty, and } \\
\text { customer risk reduction) }\end{array}$ & $\begin{array}{l}\text { Creation of dialogues } \\
\text { through information } \\
\text { technology }\end{array}$ & $\begin{array}{l}\text { Establish and develop } \\
\text { customer interactions, } \\
\text { facilitating cooperative } \\
\text { relationships and } \\
\text { mutual benefits }\end{array}$ & $\begin{array}{l}\text { Coordinated } \\
\text { interaction between } \\
\text { sellers, buyers and } \\
\text { other professionals } \\
\text { from different } \\
\text { companies, seeking } \\
\text { mutual benefits) }\end{array}$ \\
\hline & $\begin{array}{l}\text { Managerial } \\
\text { focus }\end{array}$ & $\begin{array}{l}\text { Product / brand and } \\
\text { customers (in a target } \\
\text { market) }\end{array}$ & $\begin{array}{l}\text { Management of } \\
\text { relationships between } \\
\text { the company and } \\
\text { many individuals } \\
\text { through information } \\
\text { technology }\end{array}$ & $\begin{array}{l}\text { Relationships between } \\
\text { individuals }\end{array}$ & $\begin{array}{l}\text { Networking with } \\
\text { other companies or } \\
\text { organizations }\end{array}$ \\
\hline & $\begin{array}{l}\text { Management } \\
\text { investment }\end{array}$ & $\begin{array}{l}\text { Internal marketing assets } \\
\text { (emphasis on } \\
\text { communication, and } \\
\text { information } \\
\text { technology capabilities) }\end{array}$ & $\begin{array}{l}\text { Internal operational } \\
\text { assets (IT, website, } \\
\text { logistics); Integration } \\
\text { of functional systems }\end{array}$ & $\begin{array}{l}\text { External market assets } \\
\text { (focus on establishing } \\
\text { and developing } \\
\text { relationships with other } \\
\text { individuals) }\end{array}$ & $\begin{array}{l}\text { External market } \\
\text { assets (focus on the } \\
\text { development of the } \\
\text { company's position in } \\
\text { relationship } \\
\text { networks) }\end{array}$ \\
\hline & $\begin{array}{l}\text { Management } \\
\text { level }\end{array}$ & $\begin{array}{l}\text { Marketing specialists } \\
\text { (e.g. customer service } \\
\text { manager and customer } \\
\text { account manager) }\end{array}$ & $\begin{array}{l}\text { Marketing specialists } \\
\text { with technology } \\
\text { specialists and senior } \\
\text { management }\end{array}$ & $\begin{array}{l}\text { Officials and managers } \\
\text { (from all areas / } \\
\text { functions and levels of } \\
\text { the company) }\end{array}$ & Senior management \\
\hline
\end{tabular}

Source: Coviello et al. (1997) and Coviello et al. (2001).

Coviello et al. (1997) and Coviello et al. (2001) developed a CMP model comprised of four marketing dimensions: database marketing, digital marketing, interaction marketing, and network marketing. Table 1 depicts the specific features of the model, namely: relationship with customers and other stakeholders; long-term, continuous and interactive contacts; and proximity and personalization. 
The first dimension of the relational perspective is database marketing (Dimension 1 - D1). Paas (2009) analyzed the D1 dimension in the banking, insurance and mobile telephone industries in Tanzania (Africa). The author found it difficult to apply the concept with respect to access of customer information, as well as the investment requirements for data warehouse development, and lack of specialized knowledge to take advantage of the available data. In such manner, Gregurec, Vraneevi \& Dobrini (2011) investigated the importance of database marketing for firm advertisements on social networks. The study reveals that companies that use D1 seek to increase marketing productivity, develop customer relationships and gain competitive advantage. They point out that this approach enables firms to increase customer confidence and form faster and more profitable long-term business relationships.

Now turning our attention to the digital marketing practices (D2), a sample of firms surveyed by Brodie, Winklhofer, Coviello \& Johnston (2007) revealed that 70\% of the firms adopt this approach at a moderate or high level. Digital marketing was found to be more prevalent in business to business services, as a form of integrating the other CMP components in the organization. A strong relation was found between digital marketing and company performance, particularly with respect to customer retention. On the other hand, Nobre \& Silva (2014) report that digital marketing facilitates communication with customers and provides recognition and brand awareness for small and medium-sized companies. Moreover, Rosillo \& Nencheva (2018) found that small and medium firms in Mexico prefer using digital marketing to reach their clients, either with e-mail or social media. This is because managers consider that these communication channels offer the best performance, and enable the firm to reach new customer segments and market niches.

As for the interactive marketing dimension (D3), Wagner (2005) points out that the organizations that use it tend to retain customers more effectively than their competitors, since this allows the firm to establish closer customer relationships. Conversely, Lado, Duque \& Alvarez Bassi (2013) posit that interactive marketing promotes long term relationships; promotes customer cooperation; enables personalized and interactive contacts; helps initiate and maintain interpersonal customer relationships. The survey was carried out in small consumer goods and services firms, and showed a strong relation between the interactive marketing, database marketing and network marketing approaches - which corroborates the findings of Coviello, Brodie, Brookes \& Palmer (2003). More recently, Farha \& Elbanna (2018) highlighted that in Qatar, D3 increases organizational performance, transactional marketing and interactive marketing. This result supports Farha's (2016) survey, which shows that the relational perspective produces more effective outcomes, when compared to the transactional approach.

The work of Farha et al. (2019) posits that firms merely practiced relational marketing in conjunction with transactional marketing. This could be an indication that firms still consider relational marketing a viable alternative for reaching out their customers, instead of a more appropriate view that considers this orientation to be a competitive advantage.

From the perspective of network marketing (dimension D4), Menelec \& Jones (2015) point out that this approach also occurs in community entities, commercial partners and government agencies. It generates multiple benefits for the organization, such as partner commitment, enhancement of customer confidence, ease of access to market information and facilitates brand promotion. Rogan \& Mors (2017) point out that practitioners who use the relationship networks have more information and knowledge, obtain superior business performance, enjoy greater firm autonomy, and identify market opportunities more efficiently. Table 2 presents a synthesis of the extant CMP research carried out in different contexts and countries. 
Table 2 - Synthesis of studies already done on CMP.

\begin{tabular}{|c|c|c|}
\hline Focus & Author & Main results \\
\hline \multirow[t]{5}{*}{$\begin{array}{l}\text { Classical studies } \\
\text { on the subject }\end{array}$} & Coviello et al. (1997) & $\begin{array}{l}\text { Creation of a classification scheme used to systematically examine the meaning of } \\
\text { marketing in twelve dimensions. From this schema, the authors identify two } \\
\text { "marketing" perspectives (transactional and relational), which encompass four distinct } \\
\text { marketing "types" (database marketing, interactive, network and transactional). }\end{array}$ \\
\hline & Coviello et al. (2001) & $\begin{array}{l}\text { Based on an established conceptualization of marketing practices that comprises four } \\
\text { different approaches (transaction, database, interaction and network marketing), the } \\
\text { first framework introduces a fifth approach: e-Marketing. The second structure relates } \\
\text { these five marketing approaches with three distinct roles for information technology } \\
\text { in the organization. }\end{array}$ \\
\hline & Coviello et al. (2002) & $\begin{array}{l}\text { Managers must acknowledge that companies compete using transactional marketing, } \\
\text { relational marketing or a hybrid approach. This suggests that managers need to } \\
\text { appreciate the potential role of each aspect of marketing (transaction, database, } \\
\text { interaction, and network marketing). More specifically, it can be argued that the } \\
\text { transactional market is relevant, regardless of the type of product or customer. By } \\
\text { recognizing the critical role of product, price, promotion and distribution, and by } \\
\text { learning to manage these competently, organizations can develop a solid foundation } \\
\text { for better customer relationship development. }\end{array}$ \\
\hline & Brodie et al. (2008) & $\begin{array}{l}\text { The CMP program has conducted research in more than } 15 \text { countries. The group has } \\
\text { made a unique contribution to marketing knowledge through the link between theory } \\
\text { and marketing practice. }\end{array}$ \\
\hline & $\begin{array}{l}\text { Amonini et al. } \\
(2010)\end{array}$ & $\begin{array}{l}\text { Existence of differentiation strategies, including the service quality, added value to } \\
\text { customers, strong brand investment and relationship strategies. Relationship marketing } \\
\text { tends to be viewed as a strategic approach by the organization, contributing to personal } \\
\text { interactions, customer focus, teamwork, and customer collaboration; network } \\
\text { marketing and interaction marketing are common industry practices. }\end{array}$ \\
\hline \multirow[t]{2}{*}{$\begin{array}{l}\text { Database } \\
\text { Marketing }\end{array}$} & Paas (2009) & $\begin{array}{l}\text { Used to identify customer segments. Main difficulties found in the application of } \\
\text { database marketing: lack of data; poor accessibility to customer data; absence of data } \\
\text { warehouses (to integrate different data sources in one place); lack of knowledge about } \\
\text { the application of customer data; consumers who do not update their information. }\end{array}$ \\
\hline & $\begin{array}{l}\text { Gregurec, Vraneevi } \\
\text { \& Dobrini (2011) }\end{array}$ & $\begin{array}{l}\text { Companies use database marketing for three purposes: increase marketing } \\
\text { productivity, develop customer relationships, and gain sustainable competitive } \\
\text { advantage. }\end{array}$ \\
\hline \multirow[t]{2}{*}{$\begin{array}{l}\text { Digital } \\
\text { Marketing }\end{array}$} & Day \& Bens (2005) & $\begin{array}{l}\text { Managers see the internet from a positive outlook, since through digital marketing } \\
\text { practices they can reduce service costs and allow companies to strengthen customer } \\
\text { relationships. }\end{array}$ \\
\hline & $\begin{array}{l}\text { Killian \& McManus } \\
\text { (2015) }\end{array}$ & $\begin{array}{l}\text { Social media has become an effective source of interaction between consumers and } \\
\text { brands, whereby managers can categorize media into four types: relationship } \\
\text { management, news capture, creativity and entertainment. According to the authors, not } \\
\text { a lot of academic research has attempted to understand how social media is situated } \\
\text { within the strategic marketing communication of the company. }\end{array}$ \\
\hline $\begin{array}{l}\text { Interactive } \\
\text { Marketing }\end{array}$ & $\begin{array}{l}\text { Barwise \& Farley } \\
(2005)\end{array}$ & $\begin{array}{l}\text { Interaction marketing is considered significant and rapidly growing. The industries that } \\
\text { use it more extensively are consumer, financial services and retail companies (mainly } \\
\text { B2B companies. The difference in the growth rate between countries was not } \\
\text { significant, but Japan and France were the countries with low growth. More than } 90 \% \\
\text { of companies use the Internet as a form of interaction. }\end{array}$ \\
\hline \multirow[t]{2}{*}{$\begin{array}{l}\text { Network } \\
\text { Marketing }\end{array}$} & $\begin{array}{l}\text { Menelec \& Jones } \\
(2015)\end{array}$ & $\begin{array}{l}\text { The network marketing practice generates benefits for organizations and companies } \\
\text { that participate in a network of relationships with the community, with business } \\
\text { partners and government agencies. }\end{array}$ \\
\hline & $\begin{array}{l}\text { Rogan } \\
(2017)\end{array} \quad \& \quad$ Mors & $\begin{array}{l}\text { Managers who invest in professional networks gain better performance in terms of } \\
\text { new business and knowledge; managers are exposed to a greater wealth of information, } \\
\text { autonomy for the company, and are better suited to explore new opportunities for } \\
\text { business; their contacts are more willing to provide resources in return. }\end{array}$ \\
\hline
\end{tabular}

Source: Prepared by the authors (2019).

\section{Professional Services Industry}

The professional services industry is defined by: a) their technical and specialized nature, through which the client is provided with adequate training, skills and knowledge (Gummesson, 1978; Sweeney et al., 2011; Costa, 2013 \& Patterson, 2016); b) the execution from service providers, with the participation of the client, which uses goods or equipment solely to support service delivery (Gianesi \& Correa, 2000); c) 
work by individuals that are skilled and focus on solving customer problems (Gummesson, 1978; Sweeney et al., 2011; Costa, 2013; Patterson, 2016); d) predominantly, constituted by intangible elements or custom-delivery (Reid, 2008).

The professional services industry comprises a multitude of competitors and is marked by hurdles in the achievement of sustainable and competitive differentiation (O' Mahoney, 2011). Customer relationships do contribute to organizational differentiation and performance (Menelec \& Jones, 2015); clients have a difficult time evaluating the quality of professional services in terms of their confidence, security and value - even after hiring and consuming their services (Sweeney et al., 2011; Patterson, 2016). Even so, perceived service quality is affected by what is objectively delivered (i.e., the service outcome) and the process (Sarapaivanich \& Patterson, 2015). The brand reputation and the company's image have an important role in the professional services arena, which is derived by the customer's trust (Sonmez \& Moorhouse, 2010).

It is not an easy task to monitor the employee performance in this industry, because employees are in frequent and direct contact with the client. Thus, firms are sometimes unable to fully control their production processes (Sarapaivanich \& Patterson, 2015). Clearly, customer relationships are fundamental, as they make an important contribution to the firm's competitive advantage (Reid, 2008). This relationship, however, demands a strong market orientation from the service provider, as well as consistent and effective marketing investments.

\section{Methods and Empirical Procedures}

In order to reach our desired research objectives, this study adopted a quantitative, descriptive, survey and cross-sectional survey approach. The target population is comprised of professional service companies that are formally registered under the chamber of commerce. These firms, of different sizes, provide accounting, engineering, consulting, advertising, publicity, information technology, hospitals and medical services in the State of Santa Catarina, in Brazil. The listing of these companies was obtained from the DataWash company, the Union of Advertising Agencies of Santa Catarina (SINAPRO) and by the Condor International organization, as of January 2017. The final listing contained 3,617 companies: $1,590(46.96 \%)$ are accounting service firms; 323 (8.93\%) are engineering firms; $315(8.71 \%)$ are advertising firms; $418(11.56 \%)$ are consulting firms; $746(20.62 \%)$ are information technology firms, and $225(6.22 \%)$ are medical hospitals.

A self-administered questionnaire was made available on the Google Docs platform. This questionnaire was accompanied by a personalized email invitation, sent to the initial list of companies. The questionnaire was developed using the research of Coviello et al. (1997), Coviello et al. (2001), Reid (2008) and Sweeney et al. (2011). It contains only close-ended questions (in nominal, ordinal and interval scales), in three main categories: CMP, marketing performance and company profile. The CMP scale uses a 5point Likert scale, where 0 means "I do not know", 1 means "totally disagree", and 5 means "fully agree". The scale comprises a set of statements, through which the respondent expresses his opinion (Sweeney, Williams \& Anderson, 2013). Marketing performance was measured according to a 5-point interval scale, where: 0 means "I do not know", 1 means "never uses" and 5 means "always uses", using the questions from Reid (2008) and Sweeney et al. (2011). The remainder of the questions use either nominal or ordinal scales.

The data collected was processed using the Excel 2016 and SPSS 24 software. The business size data followed the classification of Sebrae (2013) for trading companies and services. The internal consistency of the scales was measured by Cronbach's Alpha (Cronbach, 1951), and presented high reliability, both in the digital marketing dimension $(\alpha=0.906)$, network marketing $(\alpha=0.928)$, database marketing $(\alpha=$ 0.883 ), interactive marketing ( $\alpha=0.884)$, and marketing performance metrics $(\alpha=0.869)$. The Kolmogorov-Smirnov distribution normality test was applied and was found to be significant $(\mathrm{p}=0.000)$; most variables passed the normality distribution test. 


\section{Discussion of the Results}

\section{Sample profile}

146 companies participated in the study. With respect to company size, most firms are small (1 to 9 employees), and account for $48.6 \%$ of the total number of firms in the sample. Most companies have been in business for five or more years (80.9\% of the sample). Among the companies that have been in business for more than 15 years, $70 \%$ are medium and large firms. Regarding the target market, more than $50 \%$ of the companies in the sample only cater to other companies and organizations (i.e., they are in the business to business market); $34.2 \%$ both serve other companies and the end consumer (business to consumer market). Most companies provide accounting services (39.7\% of the sample), followed by information technology services (15.1\%) and consultancy (13.7\% being the "other" category). 3.4\% of the firms in the sample, are higher education companies and dental practices.

\section{Marketing investment results}

Table 3 depicts the percentage of sales invested in marketing in 2016 for the sample and broken down by company size $(\mathrm{N}=142)$. Most of the small businesses surveyed $(67 \%)$ invest up to $3 \%$ of sales turnover. This is also the case for most $(66.6 \%)$ of the medium and large size firms. 14 companies reported investing more than $9 \%$ of their revenues, of which 11 were small sized and 3 medium or large firms.

Table 3 - Percentage of sales invested in marketing - sample totals and by size.

\begin{tabular}{c|cc|cc|cc}
\hline \multirow{2}{*}{$\begin{array}{c}\text { Percent of Sales } \\
\text { invested in Marketing }\end{array}$} & \multicolumn{6}{|c}{ Companv size } \\
\cline { 2 - 7 } & \multicolumn{2}{|c|}{$\begin{array}{c}\text { Micro } \\
\text { or small }\end{array}$} & \multicolumn{2}{c}{$\begin{array}{c}\text { Medium } \\
\text { or large }\end{array}$} & \multicolumn{2}{c}{ Total } \\
\cline { 2 - 8 }$(\mathbf{2 0 1 6 )}$ & $\#$ & $\mathbf{\%}$ & $\#$ & $\mathbf{\%}$ & $\#$ & $\mathbf{\%}$ \\
\hline Up to $1 \%$ & 37 & 35.9 & 10 & 25.6 & 47 & 33.1 \\
1.1 to $3 \%$ & 32 & 31.1 & 16 & 41 & 48 & 33.8 \\
3.1 to $6 \%$ & 16 & 15.5 & 7 & 17.9 & 23 & 16.2 \\
6.1 to $9 \%$ & 7 & 6.8 & 3 & 7.7 & 10 & 7 \\
Over 9\% & 11 & 10.7 & 3 & 7.7 & 14 & 9.9 \\
\hline
\end{tabular}

Source: Prepared by the authors (2019).

Of this sample, engineering and advertising firms are the ones that invest the most in marketing. About $22.2 \%$ of engineering companies and $35.7 \%$ of advertising firms invest more than $6 \%$ of their revenues. Hospitals have already stated that they invest a maximum of $3 \%$. More than $63 \%$ of the accounting, consulting and IT firms have stated that they invest a maximum of $3 \%$ of their revenues.

\section{Results of Contemporary Marketing Practices}

Figure 1 depicts the database marketing practices (sum of percentages of scales 4 and 5) of the entire sample, and by business size (micro or small: $\mathrm{N}=76$ to 102 , medium or large $\mathrm{N}=37$ to 40 , total $\mathrm{N}=$ 113 to 142$)$.

More than half of the sample companies invest in the following database marketing activities: personalized customer service $(71.5 \%)$, direct and personalized communication $(58.8 \%)$, obtaining customer data in day-to-day negotiations $(55.7 \%)$ and communication directed at specific segments or customers (50.4\%). The database marketing practices that are less deployed by the firms are: marketing planning focused on customer segments (46.2\%), specialized professional marketing (46\%), marketing activities focused on customer retention $(44.7 \%)$ and investment in technology to communicate with clients $(44.5 \%)$. 
Figure 1 - Results of database marketing practices (total sample and by size).

Customers expect personalized contacts

Personalized direct communication

Formalized and personalized customer care

Obtain customer data via contacts

Communication directed to segments

Planning focuses segments

Person responsible for specialized marketing

Marketing focuses on customer retention

Technology investment for customer communications

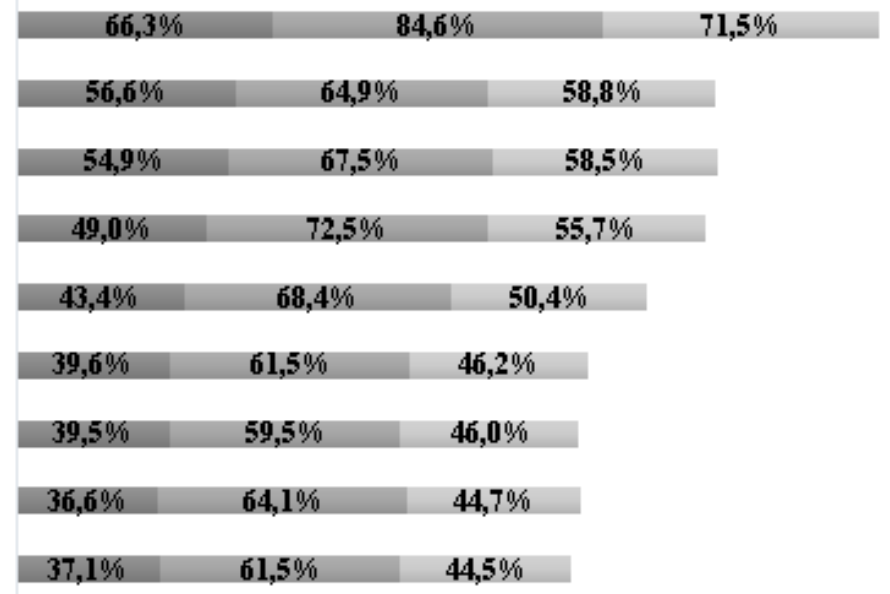

= $\%$ Small $/$ micro $\quad$ a Medium $/$ large $=\%$ T otal

Note: Micro or Small $(\mathrm{N}=76$ to 102); Medium or Large $(\mathrm{N}=37$ to 40$)$; Total $(\mathrm{N}=113$ to 142). Source: Prepared by the authors (2019).

The overall average of the sample firms in the database marketing variables is 3.4, which translates to a 'moderate' usage level. Despite this fact, eight variables present a high standard deviation (greater than $20 \%$ of the scale); this is indicative of a wide dispersion with respect to the mean (i.e., there is heterogeneity).

The differences in database marketing activity depend on the business size. All database marketing practices are often used by medium-sized companies in comparison with the small firms. In addition, more than $50 \%$ of the medium-sized companies invest in all database marketing practices. More than $50 \%$ of the small firms invest only in: personalized contacts with clients $(66.3 \%)$, direct and personalized communication (56.6\%) and informal and social services (54.9\%).

Figure 2 shows the data pertaining to the digital marketing practices of the companies surveyed (sum of the percentages of the scales 4 and 5), in total and by firm size (micro or small $\mathrm{N}=78$ to 104, medium or large $\mathrm{N}=37$ to 40 ; total $\mathrm{N}=115$ to 142 ). More than $50 \%$ of the firms surveyed invest in the following digital marketing practices: use of the internet as support in communication with clients (75.4\%), interactive contacts with clients through the Internet (71.8\%), online interaction with customers $(59.3 \%)$, personalized service via technology (56.3\%) and interaction with customers through the Internet (50.8\%). The less used digital marketing practices are: specialized marketing professional and works with technology (48.7\%), obtain data that improves the dialogue between employees and customers through the Internet (46\%), marketing activities to promote dialogues through the Internet $(42.6 \%)$ and marketing planning focused on customer relationships through the Internet (38.3\%). The overall average for the sample is 3.0, which indicates a 'moderate' use. We note that eight variables present a standard deviation greater than $20 \%$ of the scale, which is indicative of a wide dispersion from the mean. 
Figure 2 - Results of digital marketing practices (total and by size).

The Internet supports customer communications

Interactive contacts via Internet

Customer demands online interaction

Personalized customer care by technology

Invest in Internet interaction

Person responsible for specialized marketing

Obtain data from multiple intemet buyer dialog

Marketing promotes internet dialog

Planning focuses on internet relationships

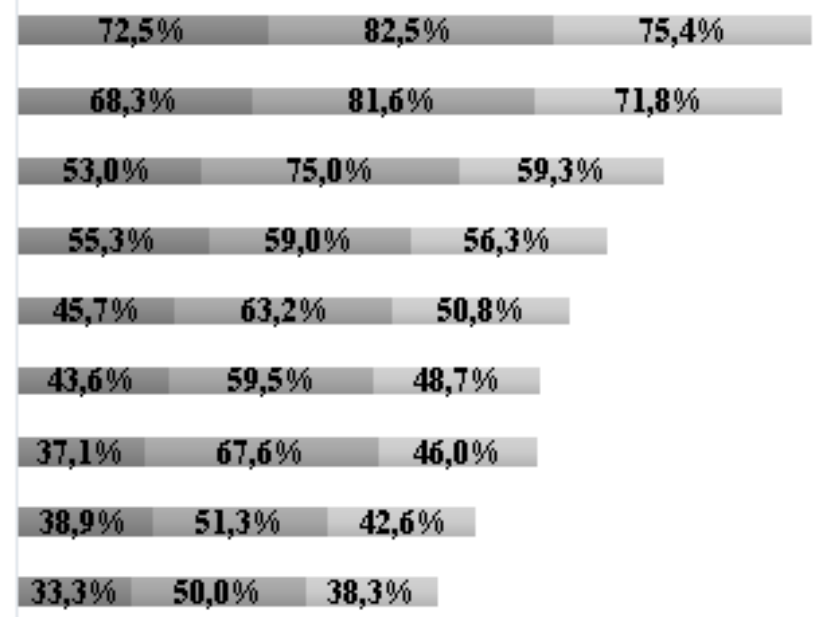

a Small $/$ micro $\quad \%$ Medium/ large $\quad \%$ T otal

Note: Micro or Small $(\mathrm{N}=78$ to 104$)$; Medium or Large $(\mathrm{N}=37$ to 40); Total $(\mathrm{N}=115$ to 142). Source: Prepared by the authors (2019).

Figure 2 shows the different practices of digital marketing in terms of business size. More than 50\% small firms invest only in: internet as support in communication with customers $(72.5 \%)$, interactive contacts with customers via the Internet (68.3\%), (55.3\%) and online interaction with clients (53\%). On the other hand, about 2 out of every 3 medium or large firms invest in almost all digital marketing practices, specifically: internet in the communication with customers $(82.5 \%)$, interactive contacts with clients via Internet $(81.6 \%)$, online interaction with clients $(75 \%)$ and to obtain data that improves the dialogue between employees and customers via the Internet $(67.6 \%)$.

Figure 3 presents the results of interactive marketing practices by company size (small $\mathrm{N}=88$ to 102, medium or large $\mathrm{N}=36$ to 40 , total $\mathrm{N}=125$ to 142 ). More than $50 \%$ of the companies surveyed invest in the following interactive marketing practices: personal and individualized service (75.4\%); to develop long-term relationships with specific clients (71.3\%); informal and social care $(59.6 \%)$; responsible for marketing also responds to other activities $(51.2 \%)$ and interpersonal contact with clients $(50.4 \%)$. The less used interactive marketing practices are: marketing communication through employees (42.3\%); personal relationship with individual clients (37.8\%); marketing activities to promote cooperative interaction with clients $(32.1 \%)$ and marketing planning focuses on the interaction with clients, and people from partner organizations $(31.5 \%)$. The overall mean of the companies surveyed in the interactive marketing variables is 3.4 , which indicates a 'moderate' use. Seven variables have a high standard deviation. 
Figure 3 - Results of interactive marketing practices (total of the sample and by size).

Customer desires individualized interaction

Develop specific customer relationships

Provide informal, social customer care

Responsible marketing functional managers

Provide interpersonal customer contact

Marketing communications from employees

Invest in personal development of individual customers

Marketing provides cooperative customer interaction

Planning focuses on special entities customer interaction

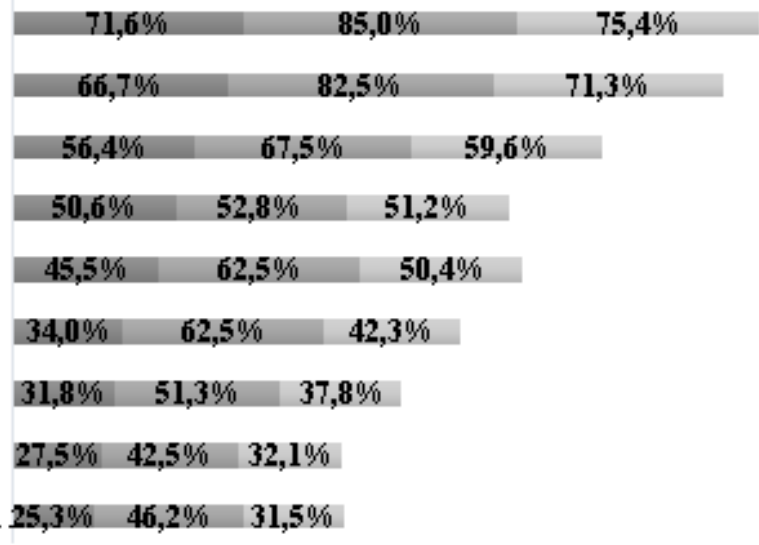

घ Small micro $\quad \square \%$ Medium large $\square \%$ T otal

Note: Small $(\mathrm{N}=88$ to 102); Medium or Large $(\mathrm{N}=36$ to 40); Total $(\mathrm{N}=125$ to 142). Source: Prepared by the authors (2019).

We found differences in the interactive marketing practices in the sample with respect to the business size. More than $50 \%$ of the medium or large companies invest more in interactive marketing practices than small firms. Most medium or large companies use the following interactive marketing practices: personal and individualized service (85\%); long-term relationship with specific clients $(82.5 \%)$; informal and social care $(67.5 \%)$; interpersonal contact with clients $(62.5 \%)$; marketing communication through employees (62.5\%); responsible for marketing also responds to other activities $(52.8 \%)$ and personal relationship development with individual clients $(51.3 \%)$. In turn, most small companies invest only in personal and individualized service (71.6\%); long-term relationship with specific clients $(66.7 \%)$; informal and social service (56.4\%) and responsible for marketing also responds to other activities / functions $(50.6 \%)$.

Figure 4 shows the results of network marketing activities in the sample, and broken down by business size (small $\mathrm{N}=87$ to 98 , medium or large $\mathrm{N}=35$ to 40 , total $\mathrm{N}=122$ to 137 ). More than $50 \%$ of the professional services companies in the sample invest in the following network marketing practices: to serve customers who wish to contact the company or other market organizations (60.9\%), and to contact the marketing or chief executive of the company (50.8\%). The least used network marketing activities are: social relationships with clients and other market organizations (43.8\%); to invest in interpersonal contacts with clients and other market organizations (43.1\%); marketing resources invested in the development of relationship networks (41.3\%); intense relationship with other market organizations (38.8\%); marketing plans to focus on the construction of relationship networks (37\%); marketing communication through managers in relationship networks (31\%); marketing actions designed to coordinate the interaction between employees, customers and other market organizations (29.7\%). The overall average of the firms in the sample with respect to the network marketing variables is 3.2 , which indicate a 'moderate' use. 
Figure 4 - Results of network marketing practices (total of the sample and by size).

Customers demand network contacts

Responsible for marketing - owner or manager

Social relationship $w /$ clients and organizations

Invest in interpersonal contacts with clients and organizations

Network development resources

Intense relationships with other organizations

Planning focuses on network development

Network marketing communications via management

Coordinated actions with employees, customers and entities

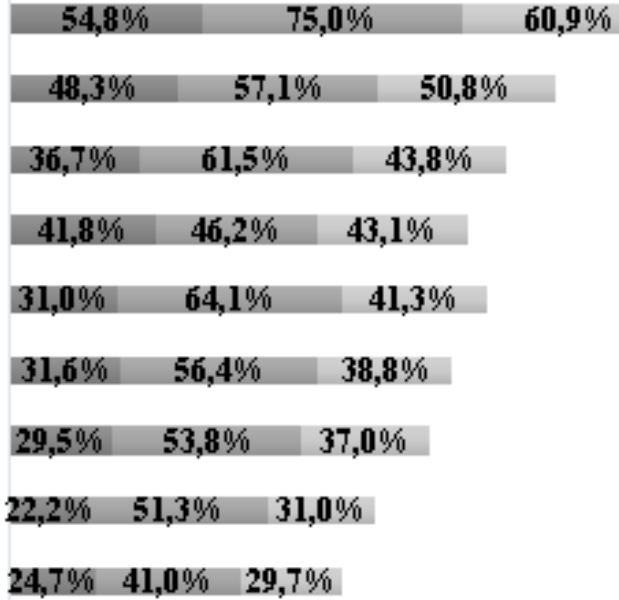

a Small/micro $\quad$ a Large/ medium $\quad \%$ T otal

Note: Small ( $\mathrm{N}=87$ to 98); Medium or Large $(\mathrm{N}=35$ to 40); Total ( $=122$ to 137$)$. Source: Prepared by the authors (2019).

There are differences in the practice of network marketing of the sampled companies with respect to the company size. Medium and large-sized firms seem to use network marketing practices more often than small firms. In addition, most medium or large companies invests in: serving customers who want to contact the company and other market organizations (75\%); has marketing resources invested in the construction of relationship networks (64.1\%); social relationships with clients and other market organizations (61.5\%); responsible for marketing is the owner or chief executive of the company $(57.1 \%)$; intense relationship with other market organizations (56.4\%); marketing planning focuses on the construction of relationship networks (53.8\%); marketing communication through managers who work in relationship networks (51.3\%). Conversely, most small businesses only invest in tools to communicate with clients who wish to contact the company, or other organizations in the market (54.8\%).

\section{Results of marketing performance metrics}

Figure 5 shows the marketing performance metrics used by the companies, broken down by business size. More than half of the companies surveyed use customer satisfaction metrics $(62.6 \%)$, customer satisfaction (57.1\%), sales growth (53.3\%) and profit margin (51.5\%). The most used metrics are return on investment $(40.3 \%)$, market share $(34.9 \%)$ and customer retention $(29.3 \%)$. The average response in the set of marketing performance metrics is 3.4 , which is indicative of a moderate use. In addition, all these variables present a high standard deviation (which indicates heterogeneity). 
Figure 5 - Results of marketing performance metrics (sample total and by size).

\begin{tabular}{|c|c|c|c|c|c|}
\hline customer satisfaction & $(\sigma=1,2 ; x=3,8)$ & $58,6 \%$ & \multicolumn{2}{|r|}{$72,5 \%$} & $62,6 \%$ \\
\hline customer acquisition & $(\sigma=1,3 ; x=3,6)$ & \multicolumn{2}{|c|}{$65,0 \%$} & $59,0 \%$ & $57,1 \%$ \\
\hline sales growth & $(\sigma=1,3 ; x=3,5)$ & $36,7 \%$ & $48,7 \%$ & $53,3 \%$ & \\
\hline profit margins & $(\sigma=1,3 ; x=3,5)$ & $36,7 \%$ & $48,7 \%$ & $51,5 \%$ & \\
\hline ROI & $(\sigma=1,4 ; x=3,1)$ & $36,7 \%$ & $48,7 \%$ & $40,39 \%$ & \\
\hline market share & $(\sigma=1,4 ; x=2,9)$ & $36,7 \%$ & $48,7 \%$ & $34,9 \%$ & \\
\hline customer retention & $(\sigma=1,3 ; x=3,7)$ & $48,7 \%$ & $27,8 \%$ & $29,3 \%$ & overall average $=3.4$ \\
\hline
\end{tabular}

Note: Micro or Small $(\mathrm{N}=90$ to 100$)$; Medium or Large $(\mathrm{N}=39$ and 40$)$; Total $(\mathrm{N}=129$ to 140). Source: Prepared by the authors (2019).

There appears to be a difference in the use of marketing performance metrics in terms of business size. Most small, medium and large sizes use customer satisfaction and new customer acquisition metrics. On the other hand, medium-sized companies use 5 out of the 7 metrics, specifically: customer satisfaction, sales growth, profit margin, return on investment and market share. In doing so, these firms use a larger set of metrics than their smaller counterparts.

\section{Results of the segmentation of the companies surveyed}

In order to perform the company segmentation, a multivariate group analysis technique was applied (Hair, Black, Babin, Anderson \& Tatham, 2009). We used: a) hierarchical agglomeration procedure; b) case processing using the Ward method; c) calculation of distance measures using quadratic Euclidean cases. The one-way ANOVA F test indicates a significant difference between the segments in the CMP. In other words, the analysis provided a heterogeneous set, in terms of CMP, of the professional service companies in the State of Santa Catarina.

Table 4 - Final centroids of the identified segments.

\begin{tabular}{l|c|c|c|c|c|c|c}
\hline \multicolumn{1}{c}{ Dimension } & \multicolumn{9}{c}{ Segments } \\
\cline { 2 - 8 } & $\mathbf{1}$ & $\mathbf{2}$ & $\mathbf{3}$ & $\mathbf{4}$ & $\mathbf{5}$ & $\mathbf{6}$ & $\mathbf{7}$ \\
\hline Database Marketing & 4.6 & 4.4 & 3.0 & 3.4 & 2.9 & 2.2 & 1.8 \\
Digital Marketing & 4.7 & 4.3 & 3.8 & 3.5 & 2.7 & 2.1 & 1.7 \\
Interactive Marketing & 4.8 & 3.8 & 4.3 & 3.4 & 2.8 & 2.6 & 1.8 \\
Network Marketing & 4.7 & 3.6 & 4.3 & 3.1 & 2.1 & 2.6 & 1.2 \\
\hline
\end{tabular}

Source: Prepared by the authors (2019).

Table 4 depicts the centroid results (central points) of each segment that was generated according to the CMP dimension. Segment 1 presents the highest values, ranging from 4.6 to 4.8. On the other hand, segments 5 to 7 are those that have the lowest values (1.2 to 2.6), which means they use less the CMP marketing practices. 
Table 5 summarizes the profile of the company segments (with name, size, CMP characteristics, marketing investment, marketing performance metrics, and changes in revenue and profitability). The segment nomenclature derives from the extant literature, and from the characteristics of the companies that comprise each segment.

Table 5 - Profile of identified segments.

\begin{tabular}{|c|c|}
\hline Cluster & Characteristics \\
\hline $\begin{array}{c}1 \\
\text { "Advanced } \\
\text { Relational" } \\
\mathbf{2 3} \text { firms }(\mathbf{1 6 . 3 \%})\end{array}$ & $\begin{array}{l}\text { Predominatly comprised of micro or large companies, with more than } 8 \text { years, in accounting and consulting services, } \\
\text { which serve only organizational markets and have invested more than } 3 \% \text { of revenues in marketing. Firms invest the } \\
\text { most in all dimensions of contemporary marketing. Most commonly used metrics are customer retention, customer } \\
\text { satisfaction, customer achievement, sales growth, and profitability. About half of the companies had an increase } \\
\text { between } 5.1 \text { to } 20 \% \text { of sales and an increase of more than } 10 \% \text { in profitability. }\end{array}$ \\
\hline $\begin{array}{l}2 \\
\text { "Interactive or } \\
\text { network } \\
\text { Relational" } \\
\mathbf{5} \text { firms } \\
(\mathbf{3 . 5 \%}) \\
\end{array}$ & $\begin{array}{l}\text { Predominatly comprised of micro-sized companies, with up to } 3 \text { years or more } 15 \text { years, accounting and consulting, } \\
\text { which serve only organizational markets and have invested up to } 1 \% \text { in marketing. Such companies invest heavily in } \\
\text { relationships with customers and other organizations, especially in interactive and network marketing. Most commonly } \\
\text { used performance metrics: sales growth, customer acquisition, and customer retention. The vast majority of them had } \\
\text { an increase equal to or greater than } 5.1 \% \text { in revenue and profitability. }\end{array}$ \\
\hline $\begin{array}{c}3 \\
\text { "Database o } \\
\text { digital Relational" } \\
\mathbf{2 4} \text { firms (17\%) }\end{array}$ & $\begin{array}{l}\text { Predominatly comprised of companies of micro or large, with } 5 \text { to } 8 \text { years or more of } 15 \text { years, of the branches of IT, } \\
\text { publicity and accounting; which serve organizational and end-consumer markets, and who invested up to } 3 \% \text { or more } \\
\text { of } 9 \% \text { in marketing. Companies that invest heavily in customer relationships, especially in database and digital } \\
\text { marketing. Most used metrics: customer conquest, customer retention, and customer satisfaction. The vast majority of } \\
\text { them had an increase equal to or greater than } 5.1 \% \text { in sales and an increase equal to or greater than } 5.1 \% \text { in } \\
\text { profitability. }\end{array}$ \\
\hline $\begin{array}{c}4 \\
\text { "Moderate } \\
\text { Relational" } \\
44 \text { firms }(31.2 \%)\end{array}$ & $\begin{array}{l}\text { Predominatly comprised of micro and small companies, with more than } 8 \text { years, of the branches accounting and T.I.; } \\
\text { which serve organizational and end-consumer markets, and have invested up to } 3 \% \text { in marketing. Companies that } \\
\text { invest moderately and equally in all of the dimensions of contemporary marketing. Most commonly used performance } \\
\text { metrics: customer satisfaction, customer retention, and customer acquisition. About } 65.1 \% \text { of them had a } 5.1 \text { to } 30 \% \\
\text { increase in sales; } 58.1 \% \text { had an increase of up to } 20 \% \text { in profitability. }\end{array}$ \\
\hline $\begin{array}{c}5 \\
\text { "Conservative I" } \\
12 \text { firms (8.5\%) }\end{array}$ & $\begin{array}{l}\text { an } 15 \text { years, accounting, engineering and IT; which } \\
\text { ested up to } 3 \% \text { in marketing. Companies that invest } \\
\text { r than the general average of the identified clusters. } \\
\text { stomer satisfaction, sales growth, and profit margin. } \\
\text { a profitability. }\end{array}$ \\
\hline $\begin{array}{c}6 \\
\text { "Conservative II" } \\
23 \text { firms (16.3\%) }\end{array}$ & $\begin{array}{l}\text { Predominatly comprised of micro or large companies, with more than } 8 \text { years, accounting, consulting and medical } \\
\text { hospitals, serving the organizational markets and final consumer and investing up to } 1 \% \text { in marketing. Companies that } \\
\text { invest little in contemporary marketing, having an average lower than the general average of the identified clusters. } \\
\text { Most used performance metrics: profit margin and customer satisfaction. About } 77.3 \% \text { of them had an increase of up to } \\
20 \% \text { in sales; } 72.7 \% \text { had an increase of up to } 20 \% \text { in profitability. }\end{array}$ \\
\hline $\begin{array}{c}7 \\
\text { "Refractive" } \\
10 \text { firms }(\mathbf{7 . 1 \%})\end{array}$ & $\begin{array}{l}\text { Micro-sized companies, with more than } 8 \text { years, predominatly in accounting and consulting, which only serve } \\
\text { organizational or final consumer markets, and have invested up to } 1 \% \text { in marketing. They are the companies that invest } \\
\text { less in all dimensions of contemporary marketing and that use less marketing performance metrics. About } 50 \% \text { of them } \\
\text { had a decrease or no increase in revenue and profitability. }\end{array}$ \\
\hline
\end{tabular}

Source: Prepared by the authors (2019).

Segment 1 (hereafter referred to as "Advanced Relational") encompasses mostly micro or large companies (73\% of the segment) and have been in business for more than 8 years $(73.9 \%)$. Accounting services correspond to $30.4 \%$, and Consulting $21.7 \%$. Firms cater to B2B markets $(56.4 \%$ ) and have invested more than $3 \%$ of marketing revenues (71.7\%) in 2016. These firms invest the most in all CMP initiatives. The most commonly used performance metrics are customer retention (average 4.5), customer satisfaction (4.5), customer acquisition (4.4), sales / revenue growth (4.4), and margin / profitability (4.4). Regarding marketing performance, $50 \%$ of the companies in this group have increased sales by $5.1 \%$ to $20 \%$ in the last 3 years; $47 \%$ had an increase of more than $10 \%$ in profitability.

Segment 2, dubbed "Interactive Relational / Network", is comprised of micro-firms ( $80 \%$ of them), with up to 3 years $(40 \%)$ or over 15 years in business (40\%), accounting firms (40\%) and consulting firms (40\%). Most only serve organizational markets (60\%) and invested up to $1 \%$ in marketing in $2016(60 \%)$. They invest heavily in relationships, mainly in interactive marketing practices (average 4.3) and network marketing $(4,3)$. The most commonly used performance metrics are sales / billings growth (4.0), customer 
acquisition (4.0) and customer retention (4.0). $80 \%$ of the firms had an increase of $5.1 \%$ or more in revenue and profitability in the past 3 years.

Segment 3, dubbed "relational database / digital", is comprised of micro and large companies (67\% of them), with 5 to 8 years $(29.2 \%$ ) or more than 15 years in business (41.7\%), Information Technology (29.2\%), Advertising (25\%) and Accounting (20.8\%). They cater to B2B and B2c markets (87.5\%), and in 2016 invested up to $3 \%(45.8 \%)$ or above $9 \%$ of sales $(29.2 \%)$ in marketing. The segment invests heavily in customer relationships, mainly in database marketing practices (average 4.4) and digital marketing (4.3). The most commonly used performance metrics are customer acquisition (4.6), customer retention (4.5) and customer satisfaction (4.4). In the last three years, $91.7 \%$ of the companies had an increase of $5.1 \%$ or higher in sales, and $73.9 \%$ had an increase of $5.1 \%$ or higher in profitability.

In segment 4, denominated "Moderate Relational", small firms are highly present (75\%), with more than 8 years in business (68.2\%), Accounting (40.9\%) and Information Technology services (25\%), which serve the B2B and B2C markets (88.6\%). In 2016, they invested up to $3 \%$ of their revenues $(69.8 \%)$ in marketing. The segment invests moderately and in a balanced manner, in all CMP approaches: digital marketing (average 3.5), database marketing (3.4), interactive marketing (3.4) and network marketing (3.1). The most used performance metrics are customer satisfaction (4.0), customer retention (3.8) and customer acquisition (3.6). $65.1 \%$ of the firms increased their sales from $5.1 \%$ to $30 \%$ in the last 3 years; $58.1 \%$ of them had an increase of up to $20 \%$ in profitability.

Segment 5, dubbed "Conservative I", is comprised of small firms ( $92 \%$ of them), with more than 15 years in business (58.3\%), in the Accounting (58.3\%), Engineering (16.7\%) and Information Technology services (16.7\%); which cater to B2B (58.3\%) or B2C markets (25\%). In 2016, they invested up to 3\% of their revenues $(75 \%)$ in marketing. The segment does not invest heavily in CMP, with below-average numbers as compared to other segments: interactive marketing (average 2.6), network marketing (2.6), database marketing (2.2) and digital marketing (2.1). The most commonly used performance metrics are customer retention (3.4), customer satisfaction (3.3), sales / revenue growth (3.3), and profit margin (3.3). $41.7 \%$ of these companies have decreased or remained flat in terms of revenue and profitability, for the last three years.

In the segment 6, called "Conservative II", micro and large companies are predominant (61\%), with more than 8 years in business (65.2\%), in the Accounting (56.5\%), Consulting (13\%) and Medical Hospitals services $(13 \%)$, serving organizational and final consumer markets $(91.3 \%)$ and invested up to $1 \%$ of their revenues $(60.9 \%)$ in marketing in 2016. The segment does not invest heavily in CMP, with an average lower than the overall sample: database marketing (2.9), digital marketing (2.7), interactive marketing (2.8) and network marketing (2.1). The most used performance metrics are profit margin (3.0) and customer satisfaction (2.9). Despite the low investment in CMP, 77.3\% of the companies in the group had, in the last 3 years, increased up to $20 \%$ in sales, and $72.7 \%$ of them had an increase of up to $20 \%$ in profitability.

Lastly, segment 7 (dubbed "Refractory") encompasses micro-sized firms ( $80 \%$ of them), with more than 8 years in business $(70 \%)$, of the Accounting and Consulting services (40\%), serving organizational or end-user markets (40\%). They invested up to $1 \%$ of their revenues $(77.8 \%)$ in marketing in 2016 . Firms in this segment invest the least in the overall CMP approaches: database marketing (average 1.8), digital marketing (1.7), interactive marketing (1.8) and network marketing (1.2). The segment is also the one that least uses marketing performance metrics - but mentioned using some of them for sales growth (2.9), customer retention (2.4) and customer satisfaction (2.4). 50\% of companies had decreased or remained flat in terms of revenue and profitability for the past 3 years. 


\section{Discussion}

Regardless of their size, companies in the sample use multiple CMP approaches from a relational perspective, but in a moderate and balanced manner (i.e. with similar intensity and mixed use of different approaches). However, medium-sized companies use relatively more Database Marketing and Digital Marketing practices, compared to micro and small firms (figures 1 and 2). This result corroborates the findings of McColl-Kennedy, Sweeney, Soutar \& Amonini (2008). In a study by Brodie et al. (2007), most small businesses used digital marketing at medium or high levels. Perhaps, as pointed out by Reid (2008), small firms find it more difficult to use database marketing, because of the lack of technological resources and specialized personnel. However, Brodie et al. (2007) and Nobre \& Silva (2014) posit that digital marketing (more specifically, Facebook) plays a relevant role to improve the relationship with the different stakeholders of the firm.

More recently, Farha et al. (2019) have found that service companies in Catar used database marketing approaches with less emphasis and less intensively than the interactive, face-to-face contact actions.

Rosillo \& Nencheva (2018) posit that small and medium-sized companies in Mexico follow global trends, and use up-to-date technologies in different areas. The developments in the marketing practices produce changes in other areas of the company, such as finance or production, to produce the desired performance results. Farha \& Elbanna's study (2018) in Qatar suggests that organizations use a greater diversity of marketing practices and approaches, such as database marketing, interactive and digital marketing.

The marketing metrics that are most used by the professional services firms are customer satisfaction, customer acquisition, sales growth, and profitability. The small and micro firms more commonly use customer acquisition, retention and satisfaction. These results contradict Reid's (2008) study in Australia, whereby firms use few customer-based metrics such as acquisition, retention and customer satisfaction. However, our results corroborate the findings of Sweeney et al. (2011) in Australia, which showed an efficient use of marketing metrics (such as customer loyalty, satisfaction and referrals).

Regarding the CMP segmentation of companies, seven segments emerged from our study: Advanced Relational, Interactive Relational / Network, Database Relational / Digital, Relational Moderate, Conservative I, Conservative II and Refractory. These results resemble those of Pels \& Brodie (2004) in Argentina (which produced six segments: Traditional I, Traditional II, Progressive I, Progressive II and Progressive III); and Targino et al. (2013) in Brazil (with five segments: Refractory, Transactional / Interactive, Advanced, Moderate, Unique), and Farha et al. (2019) in Qatar (with four segments: Transactional Marketing, Interactive e Network Marketing, Pluralistic Marketing and Low Marketing), with a perspective on the use of the CMP relational approach.

The Advanced Relational segment that emerges from this article - which is characteristic of the companies that most use CMP - has similar traits to the Advanced segment of Targino et al. (2013) and the Pluralistic Marketing segment from Farha et al. (2019). On the other hand, the Refractory segment found here encompasses companies that do not use CMP extensively; this resembles the Refractory segment of Targino et al. (2013) and the Low Marketing segment from Farha et al. (2019). Lastly, this stream of research should be concerned with personalization strategies, that comes with differentiation strategies that better position the company from the customer's perspective, thus improving its brand image.

\section{Final Considerations}

In this article, we mapped the CMP practices (database marketing, digital marketing, interactive marketing and network marketing) used by professional services firms in Santa Catarina (Brazil), their billing ratios and the marketing performance metrics that they use. Seven segments based on the CMP approach emerged from this research. 
The research provides both a synthetic and analytical data contribution with respect to the CMP practices in companies of different sizes. Our theoretical contribution reinforces the validity of the model proposed by Coviello et al. (1997) and Coviello et al. (2001) for CMP in the professional services arena.

We note that there is a shortage of empirical evidence on the subject (Reid, 2008; McColl Kennedy et al., 2008; Amonini et al., 2010; Sweeney et al., 2011). Our findings suggest that a model lends itself well to the description of CMP in the organizational context that was studied. In addition, the data came from managers and owners of the companies surveyed, whereas most CMP studies use data collected from the consumer perspective.

The results of this research will help professional service managers improve their business performance, by pointing out other contemporary CMP approaches; it will also stimulate the application of the most appropriate strategies for each company. In that sense, marketing practitioners must start with an evaluation of the company's profile, followed by the proposed CMP approach taxonomy comprised of the segment profiles herein identified. Understanding the specific changes in the use of CMP will lead to business and marketing performance. In addition, it is important to consider the firm's competitive analysis and the use of specific actions tailored to the company's characteristics, considering the existing opportunities to improve the CMP practices.

In terms of the limitations of this research, we note that the use of non-probabilistic (convenience) sampling does not allow us to generalize our findings. In addition, there was a disproportionately small participation of medium-sized companies.

In lieu of a simple marketing approach classification, the CMP perspective presupposes that alternative practices by firms not be considered mutually exclusive. Accordingly, empirical research may point out firms that deploy multiple combinations of practices (transactional, relational, network and interactive). Some firms may deploy more intense transactional actions, whereas others may place stronger emphasis of relational actions, and still other companies may have more pluralistic approaches.

Thus, the sample profile will not accurately reflect the target population of the companies surveyed. We suggest that future studies use a more representative sampling method - either selecting companies by the business size, or by using other probabilistic methods. We also suggest that quantitative studies be carried out in other Brazilian states, in order to compare results with our research. Another promising area for research is the investigation of other primary and secondary industries, as well as product categories (such as manufactured goods, industrial services, convenience services).

Qualitative CMP studies could help explain our findings and the differences in CMP by size or business activity. Further studies could analyze the Transactional Marketing approach (not considered in this paper) or other approaches that may emerge from the changing reality of marketing management. Perhaps it will be possible to compare the CMP model herein with on other rival models, such as Turnbull, Ford and Cunningham (1996), Boone \& Kurtz's (2009) or Madruga's (2015). Souza and Freitas (2016) also note the need to develop differentiated and innovative CMP research methods and techniques, since there is a prevalence of empirical, qualitative and exploratory studies. Lastly, Sarquis, Hoeckesfeld, Favretto \& Cohen (2019) demonstrate that there is a gap in terms of qualitative and quantitative studies that provide conclusive results, and use experiments and longitudinal methods.

\section{References}

Amonini, C., McColl-Kennedy, J., Soutar, G. \& Sweeney, J. (2010). How professional service firms compete in the market: an exploratory study. Journal of Marketing Management, 26(1-2), 28-55.

Barwise, P. \& Farley, J. (2005). The state of interactive marketing in seven countries: interactive marketing comes of age. Journal of Interactive Marketing, 19(3), 67-80. 
Boone, L. \& Kurtz, D. (2009). Marketing contemporâneo. Cengage Learning.

Brodie, R., Winklhofer, H., Coviello, N. \& Johnston, W. (2007). Is e-marketing coming of age? An examination of the penetration of e-marketing and firm performance. Journal of Interactive Marketing, 21(1), 2-21.

Brodie, R., Coviello, N. \& Winklhofer, H. (2008). Investigating contemporary marketing practices: a review of the first decade of the CMP research program. Journal of Business and Industrial Marketing, 23(2), 84-94.

Centeno, E. \& Hart, S. (2012). The use of communication activities in the development of small to medium-sized enterprise brands. Marketing Intelligence and Planning, 30(2), 250-265.

Costa, L. (2013). Estratégias e práticas de marketing relacional de pequenas empresas de serviços profissionais especializados em arquitetura. Dissertação de Mestrado - Escola de Economia e Gestão, Universidade do Minho - Portugal.

Coviello, N., Brodie, R. \& Munro, H. (1997). Understanding contemporary marketing: development of a classification scheme. Journal of Marketing Management, 13(6), 501-522. Doi: https://doi.org/10.1080/0267257x.1997.9964490

Coviello, N., Milley, R. \& Marcolin, B. (2001). Understanding IT-enabled interactivity in contemporary marketing. Journal of Interactive Marketing, 15(4), 18-33. Doi: https://doi.org/10.1002/dir.1020

Coviello, N. \& Brodie, R. (2001). Contemporary marketing practices of consumer and business-tobusiness firms: how different are they? Journal of Business and Industrial Marketing, 16(5), 382-400.

Coviello, N., Brodie, R., Danaher, P. \& Johnston, W. (2002). How firms relate to their markets: an empirical examination of contemporary marketing practices. Journal of Marketing, 66(3), 33-46. Doi: https://doi.org/10.1509/jmkg.66.3.33.18500

Coviello, N., Brodie, R., Brookes, R. \& Palmer, R. (2003). Assessing the role of e-marketing in contemporary marketing practice. Journal of Marketing Management, 19(7-8), 857-881.

Coviello, N., Winklhofer, H. \& Hamilton, K. (2006). Marketing practices and performance of small service firms an examination in the tourism accommodation sector. Journal of Service Research, 9 (1), 38-58.

Day, G. \& Bens, K. (2005). Capitalizing on the internet opportunity. Journal of Business and Industrial Marketing, 20(4/5), 160-168.

De Macedo Bergamo, F., Giuliani, A. \& Galli, L. (2011). Modelo de lealdade e retenção de alunos para instituições do ensino superior: um estudo teórico com base no marketing de relacionamento. BBRBrazilian Business Review, 8(2), 43-66.

Ekman, P., Erixon, C. \& Thilenius, P. (2015). Information technology utilization for industrial marketing activities: the IT-marketing gap. Journal of Business and Industrial Marketing, 30(8), 926-938.

Farha, A. (2016). Matching organizational frame of reference and business strategy with contemporary marketing practices: Evidence from Arab World. International Journal of Emerging Markets, 11(4), 533-549.

Farha, A. \& Elbanna, S. (2018). Do different marketing practices pre-suppose different frames of reference? An exploratory study. Journal of Business and Industrial Marketing, 33(3), 337-352.

Farha, A. K. A., Koku, P. S., Al-Kwifi, S. O. \& Ahmed, Z. U. (2019). Services marketing practices in diverse cultures: Canada compared to Qatar. Journal of Services Marketing, 33(7), 771-782.

Faria, L., Giuliani, A., Pizzinatto, N. \& Spers, V. (2014). 20 anos de publicações sobre marketing de relacionamento no Brasil: uma análise da produção acadêmica de 1992 a 2012. Revista Brasileira de Marketing, 13(1), 106-118. 
Gianesi, I. \& Corrêa, H. (2000). Administração estratégica de serviços: operações para a satisfação do cliente. São Paulo: Atlas.

Gregurec, I., Vraneevi, T. \& Dobrini, D. (2011). The importance of database marketing in social network advertising. International Journal of Management Cases, 13(4), 165-172.

Gummesson, E. (1978). Toward a theory of professional service marketing. Industrial Marketing Management, 7(2), 89-95.

Hoeckesfeld, L., Sarquis, A. \& Favretto, J. (2017). Análise da produção científica sobre práticas contemporâneas de marketing. In: SemeAd - Seminários em Administração da Faculdade de Economia, Administração e Contabilidade da Universidade de São Paulo, São Paulo - SP. Anais do XX SemeAd PPGA FEA USP.

IBGE - Instituto Brasileiro de Geografia e Estatística (2016). Pesquisa Anual de Serviços. https://www.ibge.gov.br/estatisticas-novoportal/economicas/servicos/9028-pesquisa-anual-deservicos.html

Ibis World. (2016). Professional services in Australia: Market Research Report. https://www.ibisworld.com.au/industry/professional-services.html

Killian, G. \& McManus, K. (2015). A marketing communications approach for the digital era: Managerial guidelines for social media integration. Business Horizons, 58(5), 539-549.

Lado, N., Duque, L. \& Alvarez Bassi, D. (2013). Current marketing practices and market orientation in the context of an emerging economy: the case of Uruguay. Journal of Small Business Management, 51(4), 602616.

Lindgreen, A., Di Benedetto, C. A., Brodie, R. J. \& Naudé, P. (2019). How to build great research groups. Industrial Marketing Management, 81, 1-13. Doi: https://doi.org/10.1016/j.indmarman.2019.07.009

Little, V., Brookes, R. \& Palmer, R. (2008). informed teaching and teaching-informed research: the contemporary marketing practices living case study approach to understanding marketing practice. Journal of Business and Industrial Marketing, 23(2), 124-134.

McColl-Kennedy, J., Sweeney, J., Soutar, G. \& Amonini, C. (2008). Professional service firms are relationship marketers: but does size matter? Australasian Marketing Journal, 16(1), 30-47. Doi: https://doi.org/10.1016/s1441-3582(08)70003-x

Menelec, V. \& Jones, B. (2015). Networks and marketing in small professional service businesses. Journal of Research in Marketing and Entrepreneurship, 17(2), 193-211. Doi: https://doi.org/10.1108/JRME-03-20150023

Nobre, H. \& Silva, D. (2014). Social network marketing strategy and SME strategy benefits. Journal of Transnational Management, 19(2), 138-151.

O' Dwyer, M., Gilmore, A. \& Carson, D. (2009). Innovative marketing in SMEs. European Journal of Marketing, 43(1/2), 46-61. Doi: https://doi.org/10.1108/03090560910923238

O' Mahoney, J. (2011). Management innovation in the UK consulting industry. Instituto Avançado de Pesquisa e Gerenciamento. Londres.

Paas, L. (2009). Database marketing practices and opportunities in a newly emerging African market. Journal of Database Marketing and Customer Strategy Management, 16(2), 92-100.

Patterson, P. (2016). Retrospective: tracking the impact of communications effectiveness on client satisfaction, trust and loyalty in professional services. Journal of Services Marketing, 30(5), 485-489. Doi: https://doi.org/10.1108/JSM-05-2016-0190

Reid, M. (2008). Contemporary marketing in professional services. Journal of Services Marketing, 22(5), 374384. Doi: https://doi.org/10.1108/08876040810889148 
Rocha, A. \& Luce, F. (2006). Relacionamentos entre compradores e vendedores: origens e perspectivas no marketing de relacionamento. Revista de Administração de Empresas, 46(3), 87-93.

Rogan, M. \& Mors, M. (2017). Managerial networks and exploration in a professional service firm. Organization Studies, 38(2), 225-249.

Rosillo, H. \& Nencheva, V. (2018). Contemporary marketing practices in Mexico. Economic Alternatives, (2), 239-249.

Sacramento, P. \& Teixeira, R. (2014). Adoção de inovações em empresas de pequeno e médio porte: estudo de casos múltiplos em negócios hoteleiros na cidade de Aracaju. Revista Organizações em Contexto, 10(19), 1-30. Doi: http://dx.doi.org/10.15603/1982-8756/roc.v10n19p1-30

Sarapaivanich, N. \& Patterson, P. (2015). The role of interpersonal communication in developing smallmedium size enterprise (SME) client loyalty toward an audit firm. International Small Business Journal, 33(8), 882-900.

Sarquis, A. B., Hoeckesfeld, L., Favretto, J. \& Cohen, E. D. (2019). An Analysis of the International Scientific Production on Contemporary Marketing Practices. Revista Pensamento Contemporaneo em Administração, 13(1), 100-122.

Siluk, J. \& Nora, L. (2011). Proposta de diagnóstico da inovação e competitividade no setor de serviços. RACE-Revista de Administração, Contabilidade e Economia, 10(1), 7-30.

Soares, F. \& Monteiro, P. (2015). Marketing digital e marketing de relacionamento: interação e engajamento como determinantes do crescimento de páginas do Facebook. Navus: Revista de Gestão e Tecnologia, 5(3), 42-59.

Sonmez, M. \& Moorhouse, A. (2010). Purchasing professional services: which decision criteria? Management Decision, 48(2), 189-206.

Souza, L. L. F. \& Freitas, A. A. F. (2016). Revisão da produção científica brasileira em segmentação de mercado. Revista de Ciências da Administração, 18(45), 96-108.

Sweeney, J., Soutar, G. \& McColl-Kennedy, J. (2011). The marketing practices-performance relationship in professional service firms. Journal of Service Management, 22(3), 292-316. Doi: https://doi.org/10.1108/09564231111136845

Targino, L., Urdan, A. \& Chauvel, M. (2013). As práticas de marketing, entre transações e relacionamentos, de empresas no Brasil. Brazilian Business Review - BBR, 10(2), 124-141.

Turnbull, P., Ford, D. \& Cunningham, M. (1996). Interaction, relationships and networks in business markets: An evolving perspective. Journal of Business and Industrial Marketing, 11(3/4), 44-62. Doi: https://doi.org/10.1108/08858629610125469

Zeithaml, V., Bitner, M. \& Gremler, D. (2014). Marketing de serviços: a empresa com foco no cliente. AMGH Editora

Wagner, R. (2005). Contemporary marketing practices in Russia. European Journal of Marketing, 39 (1), 199215. 